\title{
Chiral Protonated Amino Acid Ester Discrimination by Acyclic Chiral Hosts Including D-Mannofuranose Moieties in Fast Atom Bombardment Mass Spectrometry Coupled with the Enantiomer Labeled Guest Method
}

\author{
Motohiro Shizuma, ${ }^{1 *}$ Hirofumi Sato, ${ }^{1}$ Yoshio Takal, ${ }^{2}$ Daisuke Ono, ${ }^{1}$ \\ Takeyuki Suzuki, ${ }^{2}$ and Masaki NAKAmura ${ }^{1}$ \\ ${ }^{1}$ Department of Biochemistry, Osaka Municipal Technical Research Institute, Osaka, JAPAN \\ ${ }^{2}$ Materials Analysis Center, The Institute of Scientific and Industrial Research, Osaka University, \\ Ibaraki, OSAKA, JAPAN
}

\begin{abstract}
Chiral discrimination by novel chiral hosts 3 and 4 , which consist of an oxyethylene chain and 2,3:5,6di- $O$-cyclohexylidene- $\beta$-D-mannofuranose moieties at both ends, was examined considering several protonated amino acid isopropyl ester guests using fast atom bombardment mass spectrometry (FABMS) with the enantiomer deuterium-labeled guest method. Host 3 showed chiral discrimination toward several guests but with slightly smaller chiral discrimination abilities than host $\mathbf{2 a}$, which consists of a bis-(oxyethylene) chain and 1,2: 3,4-di-O-isopropylidene- $\alpha$-D-galactopyranoside moieties at both ends. Host 4 showed no enantioselectivity, possibly because chiral hosts do not show a pseudo-ring conformation having large open spaces in complexations with a chiral guest in regard to the steric effects of cyclohexylidene groups. In addition, to understand the chiral recognition mechanisms, the binding sites of hosts 3 and 4 were elucidated by ultraviolet-visible (UV-VIS) and proton nuclear magnetic resonance $\left({ }^{1} \mathrm{H}-\mathrm{NMR}\right)$ spectroscopy.
\end{abstract}

(Received April 17, 2009; Accepted June 17, 2009)

\section{Introduction}

Chiral recognition is a fundamental and significant process in living systems. Many chiral-recognizable compounds have been designed and synthesized, and their chiral recognition abilities and mechanisms have been examined by various methods. ${ }^{1-3)}$

As a method for evaluation of the chiral discrimination ability of new chiral hosts using mass spectrometry, the fast atom bombardment mass spectrometry (FABMS)/enantiomer labeled (EL) guest method proposed by Sawada et al. is widely known owing to its quantitative analysis, facile sample preparation, and short measurement time. ${ }^{4)-7)}$ However, the FABMS/EL guest method has not yet found many chiral hosts. Permethylated $1^{\mathrm{F}}$-fructonystose $(\mathbf{1})$, which shows remarkably high chiral discrimination ability toward chiral ammonium ion guests, was discovered from more than thirty permethylated oligosaccharides by screening using the FABMS/EL guest method (Chart 1). ${ }^{8)}$ 9) Oligosaccharide (1) consists of four $\beta(2 \rightarrow 1)$ linked D-fructofuranose units and an $\alpha$-glucopyranoside at the reducing end. Therefore, it consists of an oxyethylene chain moiety, which becomes a strong binding site for ammonium ions, as the backbone. In fact, host $\mathbf{1}$ efficiently discriminates the enantiomers of

* Correspondence to: Motohiro Shizuma, Department of Biochemistry, Osaka Municipal Technical Research Institute, 1-6-50 Morinomiya, Joto-ku, Osaka 536-8553, JAPAN, e-mail: shizuma@omtri.city.osaka.jp several chiral ammonium ions, such as protonated amino acid esters and $\alpha$-trialkylammonium ions. ${ }^{10)}$

On the basis of the structural features of host $\mathbf{1}$, chiral host $\mathbf{2} \mathbf{a}$ was designed and synthesized to recognize the chirality of chiral ammonium ions (Chart 1). ${ }^{11)}$ Another deuterium-labeled enantiomer (2b) was synthesized for easy synthesis in two steps. A 1/1 equivalent mixture of $\mathbf{2 a}$ and $\mathbf{2} \mathbf{b}$ was applied for enantiomeric excess (ee)-determination of $e e$-unknown chiral ammonium ions by the FABMS/EL host method. ${ }^{12)}$ The enantiomeric host pair $(\mathbf{2 a}$ and $\mathbf{2 b})$ was used for ee-determination of chiral secondary ammonium ions, which were otherwise difficult to be discriminated by the conventional cyclic chiral hosts, such as chiral crown ethers. However, specific chiral crown ether and podand-type hosts were reported to discriminate the chirality of secondary amines. ${ }^{13)-17)}$ The following are the significant features of chiral discrimination toward chiral ammonium ions: (1) a strong ammonium ion binding site, such as the oxyethylene chain moiety; and (2) steric substituent groups, such as the isopropylidene group, which provide a chiral recognizable environment for the chiral center of the chiral guests.

This paper reports the chiral discrimination of novel chiral hosts ( 3 and $\mathbf{4}$ ) toward chiral ammonium ions by the FABMS/EL guest method (Chart 2). These hosts have cyclohexylidene groups, which are more sterically bulky than isopropylidene groups. The steric effects on chiral discrimination are discussed in comparison with the case of host 2a. Further, the chiral recognition mechanisms of 3 and 4 toward chiral am- 


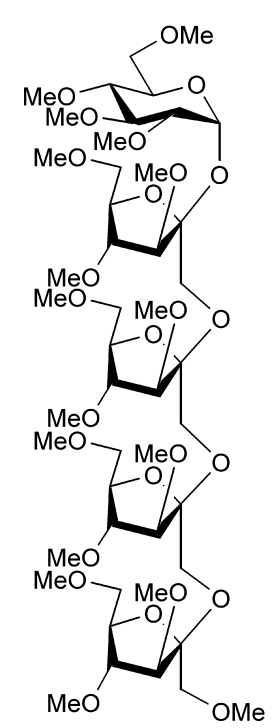

1

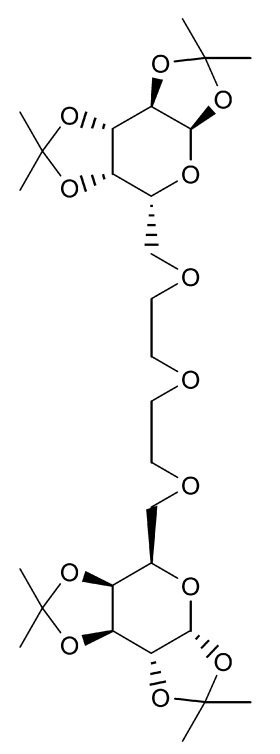

2a

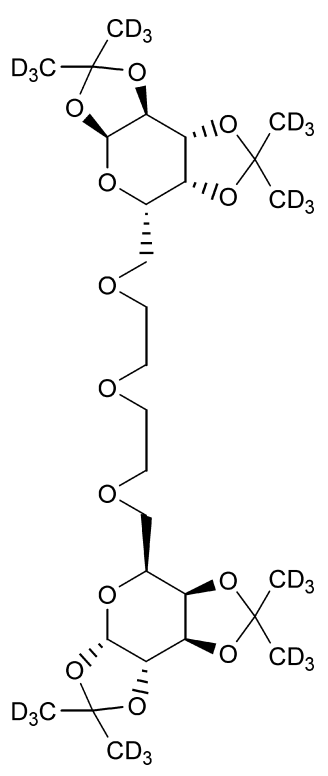

2b

Chart 1. Typical acyclic chiral hosts (1, 2a, and $\mathbf{2 b})$.

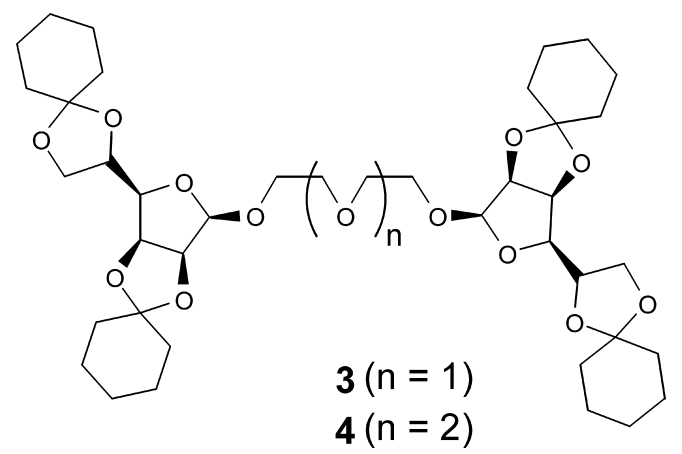

Chart 2. The synthesized acyclic hosts (3 and 4).

monium ions were perceived on the basis of the complex structures of 3 and 4 with unsubstituted ammonium ions, elucidated by ultraviolet-visible (UV-VIS) and proton nuclear magnetic resonance $\left({ }^{1} \mathrm{H}-\mathrm{NMR}\right)$ spectroscopy.

\section{Experimental}

\subsection{General procedures}

FAB mass spectra (positive mode) were acquired with a JMS-600 mass spectrometer (JEOL) operating at an accelerating voltage of $3 \mathrm{kV}$ (mass range, $m / z=50-$ 2,300). The instrument was equipped with a standard JEOL FAB source and an ion gun. Atomic beam of xenon was used with an emission current of $10 \mathrm{~mA}$ and acceleration of $6 \mathrm{kV}$. The source pressure was typically $1-2 \times 10^{-5}$ Torr. Spectra were obtained with a magnet scan rate of $10 \mathrm{~s} \mathrm{scan}^{-1}$, and the data were processed with a JEOL JMA data processing system on a UNIX system. Calibration was carried out with CsI.

${ }^{1} \mathrm{H}-\mathrm{NMR}(300 \mathrm{MHz})$ and carbon nuclear magnetic resonance $\left({ }^{13} \mathrm{C}-\mathrm{NMR}\right)(75 \mathrm{MHz})$ spectra were taken with a JNM AL-300 spectrometer (JEOL). TMS was used as the internal standard ( $\delta 0 \mathrm{ppm})$. UV-VIS spectra were obtained with a UV-3100B spectrometer (Shimadzu). Fourier transform-infra-red (FT-IR) spectra were taken with an FT-IR 8100 (Shimadzu). The specific rotation values were measured with a P-1020 polarimeter (JASCO) at $25^{\circ} \mathrm{C}$. Elemental analysis was performed with an EA1110 CHNS-O instrument (CE Instrument).

\subsection{Materials}

The following were the materials used: (1) 18-crown6 (Aldrich) without purification, (2) ammonium thiocyanate (Wako) after drying overnight at $120^{\circ} \mathrm{C}$, (3) 3-nitrobenzyl alcohol (NBA, Aldrich) as the matrix of FABMS without purification, (4) spectral grade tetrahydrofran (THF) and chloroform (both from Dojin) for the UV-VIS measurements, (5) acetone- $d_{6}$ (99.9 atom\% D) and chloroform- $d$ (both from Aldrich) for the NMR measurements, and (6) other distilled organic solvents.

\subsection{Preparation of ammonium ion guest}

$(R)$-Amino acid isopropyl ester hydrochlorides were prepared from the esterification of D-amino acid and 2propanol with hydrochloride catalyst. ${ }^{18)}$ Deuteriumlabeled (S)-amino acid isopropyl ester hydrochlorides were synthesized using deuterated 2-propanol- $d_{8}(99.5$ atom $\% \mathrm{D}, \mathrm{CDN}$ isotope). In the case of (S)-tryptophan isopropyl- $d_{6}$ ester hydrochloride, 2-propanol- $d_{6}(99.5$ atom\% D) was used to avoid hydrogen/deuterium (H/ D) exchange of the indole moiety. The products were identified by ${ }^{1} \mathrm{H}-\mathrm{NMR}$, mass spectrometry (MS), and elemental analysis, and dried in vacuo at $40^{\circ} \mathrm{C}$ overnight before the FABMS measurements. The prepared chiral ammonium ion guests are listed in Chart 3.

Ammonium picrate and $(R)-\operatorname{Trp}-\mathrm{O}-{ }^{i} \mathrm{Pr}^{+}$picrate were prepared by neutralization of picric acid and corresponding amine solutions in benzene and recrystallized in water. ${ }^{19)}$ The products were identified with elemental analysis.

2.4 Synthesis of chiral hosts 3 and 4

Hosts 3 and 4 were synthesized according to the 
<smiles>[R]OC(=O)[C@H](C)N</smiles>

Ala-O- ${ }^{\prime} \mathrm{Pr}^{+}\left(\mathrm{Cl}^{-}\right)^{a}$<smiles>[R]OC(=O)[C@@H]([NH3+])C(C)C</smiles>

Val-O-'Pr ${ }^{+}\left(\mathrm{Cl}^{-}\right)^{a}$<smiles>[R]OC(=O)[C@@H](N)CCSC</smiles>

Met-O- ${ }^{i} \mathrm{Pr}^{+}\left(\mathrm{Cl}^{-}\right)^{a}$<smiles>[R]OC(=O)[C]1CCCN1</smiles>

Pro-O- ${ }^{i} \mathrm{Pr}^{+}\left(\mathrm{Cl}^{-}\right)^{a}$<smiles>[R]OC(=O)C(N)Cc1ccccc1</smiles><smiles>[R]OC(=O)C([NH3+])Cc1c[nH]c2ccccc12</smiles><smiles>[R]OC(=O)C([NH3+])c1ccccc1</smiles>

a $(R)$-isomer $\mathrm{R}=\mathrm{CH}\left(\mathrm{CH}_{3}\right)_{2}$ $(S)$-isomer $\mathrm{R}=\mathrm{CD}\left(\mathrm{CD}_{3}\right)_{2}$

$b(R)$-isomer $\mathrm{R}=\mathrm{CH}\left(\mathrm{CH}_{3}\right)_{2}$ (S)-isomer $\mathrm{R}=\mathrm{CH}\left(\mathrm{CD}_{3}\right)_{2}$

Phe-O- ${ }^{j} \mathrm{Pr}^{+}\left(\mathrm{Cl}^{-}\right)^{a} \quad$ Trp-O- ${ }^{i} \mathrm{Pr}^{+}\left(\mathrm{Cl}^{-}\right)^{b} \quad$ Pgly-O- ${ }^{j} \mathrm{Pr}^{+}\left(\mathrm{Cl}^{-}\right)^{a}$

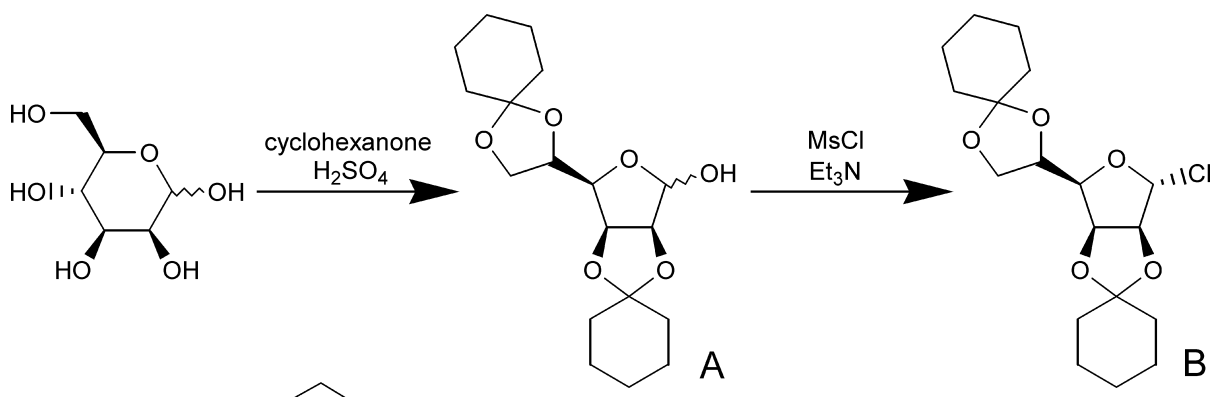

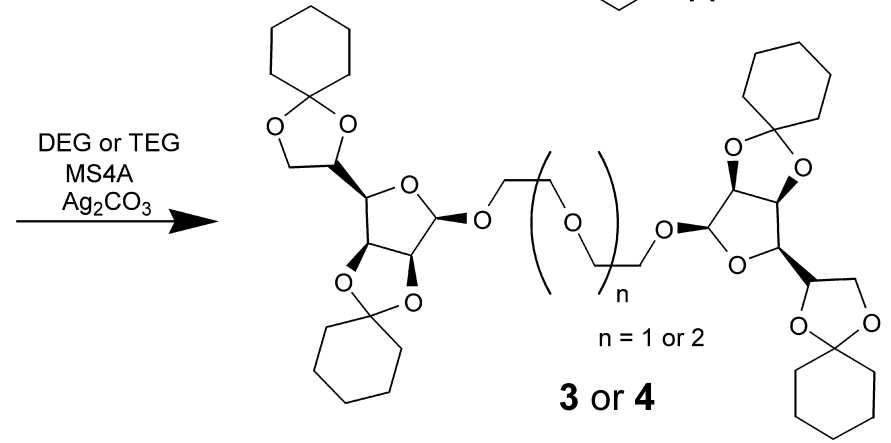

Scheme 1. Synthetic pathway of hosts 3 and 4. Abbreviations of the reagents are shown in the experimental part (2.4).

following procedures (Scheme 1): D-mannose (600 mg, $3.33 \mathrm{mmol})$ and cyclohexanone (1.5 mL, ca. $15 \mathrm{mmol})$ were stirred with sulfuric acid $(97 \%, 0.67 \mathrm{~mL})$ at room temperature over $12 \mathrm{~h}^{20)}$ Diethyl ether was added to the solution and later it was removed by decantation. After washing with aqueous sodium hydrogen carbonate and then with water, the organic layer was dried over anhydrous magnesium sulfate and the solvent was evaporated. The residue was recrystallized in $n$-hexane/diethyl ether to obtain compound A as colorless crystal (750 mg, 68\%), with the following properties: mp, $121-122^{\circ} \mathrm{C}$; ${ }^{1} \mathrm{H}-\mathrm{NMR}\left(300 \mathrm{MHz}, \mathrm{CDCl}_{3}\right) \delta 5.39$ $\left(\mathrm{d}, 1 \mathrm{H},{ }^{3} \mathrm{~J}_{1, \mathrm{OH}}=2.3 \mathrm{~Hz}, \mathrm{H} 1\right), 4.78\left(\mathrm{dd}, 1 \mathrm{H},{ }^{3} \mathrm{~J}_{2,3}=5.9 \mathrm{~Hz}\right.$, $\left.{ }^{3} J_{3,4}=3.6 \mathrm{~Hz}, \mathrm{H} 3\right), 4.60\left(\mathrm{~d}, 1 \mathrm{H},{ }^{3} J_{2,3}=5.9 \mathrm{~Hz}, \mathrm{H} 2\right), 4.43$ (dd, $\left.1 \mathrm{H},{ }^{3} J_{4,5}=5.9 \mathrm{~Hz},{ }^{3} J_{5,6}={ }^{3} J_{5,6^{\prime}}=12.0 \mathrm{~Hz}, \mathrm{H} 5\right), 4.26(\mathrm{dd}, 1 \mathrm{H}$, $\left.{ }^{3} J_{3,4}=3.6 \mathrm{~Hz},{ }^{3} J_{4,5}=5.9 \mathrm{~Hz}, \mathrm{H} 4\right), 4.04\left(\mathrm{~m}, 2 \mathrm{H}, \mathrm{H} 6, \mathrm{H}^{\prime}\right)$, 2.46 (broad, $1 \mathrm{H}, \mathrm{OH}), 1.66-1.32(\mathrm{~m}, 20 \mathrm{H}$, protons of cyclohexylidene groups); ${ }^{13} \mathrm{C}-\mathrm{NMR}\left(75 \mathrm{MHz}, \mathrm{CDCl}_{3}\right.$ ) $\delta 113.4,109.4,101.5,85.2,80.5,79.4,73.1,65.9,36.4$, 35.7, 34.7, 34.2, 25.2, 25.1, 24.1, 24.0, 23.9, 23.7.

Compound A (300 mg, $0.88 \mathrm{mmol})$ and triethylamine
$\left(\mathrm{Et}_{3} \mathrm{~N}, 0.9 \mathrm{~mL}\right)$ were dissolved in dry dichloromethane $(10 \mathrm{~mL})$. Methanesulfonyl chloride (MsCl, $0.45 \mathrm{~g}, 3.80$ $\mathrm{mmol})$ in dichloromethane $(0.1 \mathrm{~mL})$ was added to the solution dropwise over $10 \mathrm{~min}$, and stirred at $40^{\circ} \mathrm{C}$ for $2 \mathrm{~h}$ under nitrogen atmosphere. ${ }^{21)}$ After cooling to room temperature, the solution was washed with water, dried over silica gel, and evaporated. The residue was purified by liquid chromatography (filler, silica gel; eluate, $n$-hexane/ethyl acetate $=1: 3, \mathrm{v} / \mathrm{v}$ ) to obtain compound $\mathrm{B}$ as pale yellow syrup (165 mg, 52\%). ${ }^{1} \mathrm{H}-$ NMR $\left(300 \mathrm{MHz}, \mathrm{CDCl}_{3}\right)$ d 6.09 (s, 1H, H1), 4.95 (d, 1H, $\left.{ }^{3} J_{2,3}=5.9 \mathrm{~Hz}, \mathrm{H} 2\right), 4.86\left(\mathrm{dd}, 1 \mathrm{H},{ }^{3} J_{2,3}=5.9 \mathrm{~Hz},{ }^{3} J_{3,4}=3.6\right.$ $\mathrm{Hz}, \mathrm{H} 3), 4.45\left(\mathrm{~m}, 1 \mathrm{H},{ }^{3} J_{4,5}=6.7 \mathrm{~Hz},{ }^{3} J_{5,6}=6.4 \mathrm{~Hz},{ }^{3} J_{5,6^{\prime}}=\right.$ $5.2 \mathrm{~Hz}, \mathrm{H} 5), 4.26\left(\mathrm{dd}, 1 \mathrm{H},{ }^{3} J_{3,4}=3.6 \mathrm{~Hz},{ }^{3} J_{4,5}=6.7 \mathrm{~Hz}, \mathrm{H} 4\right)$, $4.07\left(\mathrm{dd}, 1 \mathrm{H},{ }^{3} J_{5,6}=6.4 \mathrm{~Hz},{ }^{3} J_{6,6^{\prime}}=8.7 \mathrm{~Hz}, \mathrm{H} 6\right), 4.00(\mathrm{dd}$, $\left.1 \mathrm{H},{ }^{3} J_{5,6^{\prime}}=5.2 \mathrm{~Hz},{ }^{3} J_{6,6^{\prime}}=8.7 \mathrm{~Hz}, \mathrm{H}^{\prime}\right), 1.66-1.24(\mathrm{~m}, 20 \mathrm{H}$, protons of cyclohexylidene groups).

Diethylene glycol (DEG, $15 \mathrm{mg}, 0.14 \mathrm{mmol}$ ) or triethylene glycol (TEG, $21 \mathrm{mg}, 0.14 \mathrm{mmol}$ ), compound B (100 mg, $0.28 \mathrm{mmol}$ ), silver carbonate (700 mg, 2.5 $\mathrm{mmol}$ ), and molecular sieves 4A (MS4A, $1 \mathrm{~g}$ ) were 
added to dry dichloromethane $(50 \mathrm{~mL})$ under a light shading condition. ${ }^{22)}$ The slurry was stirred at room temperature for 4 days under nitrogen atmosphere. After the mixture was filtered, the filtrate was evaporated and the residue was purified by liquid chromatography (filler, silica gel; eluate, $n$-hexane/ ethyl acetate/methanol $=5: 5: 1, \mathrm{v} / \mathrm{v} / \mathrm{v})$. The yields of 3 and 4 were $39 \%$ and $35 \%$, respectively. In the case of 3 , by-products such as $\alpha$ - and $\beta$-mannofuranose were isolated (yield 19\%).

The following are the physical and spectral properties of 3: colorless syrup; FABMS, $m / z 773(\mathrm{M}+$ $\mathrm{Na}){ }^{+} ;{ }^{1} \mathrm{H}-\mathrm{NMR}\left(300 \mathrm{MHz}, \mathrm{CDCl}_{3}\right) \delta 4.78\left(\mathrm{~d}, 1 \mathrm{H},{ }^{3} J_{1,2}=2.5\right.$ $\mathrm{Hz}, \mathrm{H} 1), 4.66\left(\mathrm{dd}, 1 \mathrm{H},{ }^{3} J_{2,3}=6.0 \mathrm{~Hz},{ }^{3} J_{3,4}=3.7 \mathrm{~Hz}, \mathrm{H} 3\right)$, $4.61\left(\mathrm{dd}, 1 \mathrm{H},{ }^{3} J_{1,2}=3.5 \mathrm{~Hz},{ }^{3} J_{2,3}=6.0 \mathrm{~Hz}, \mathrm{H} 2\right), 4.43(\mathrm{dt}, 1 \mathrm{H}$, $\left.{ }^{3} J_{4,5}={ }^{3} J_{5,6}=5.7 \mathrm{~Hz}, \mathrm{H} 5\right), 4.05$ (d, $2 \mathrm{H},{ }^{3} J_{5,6}=5.7 \mathrm{~Hz}, \mathrm{H} 6$ ), $3.92\left(\mathrm{dt}, 1 \mathrm{H},{ }^{3} J_{\mathrm{a}, \mathrm{b}}=5.0 \mathrm{~Hz},{ }^{2} J_{\mathrm{a}, \mathrm{a}^{\prime}}=10.6 \mathrm{~Hz}, \mathrm{Ha}\right), 3.77(\mathrm{dt}$, $\left.1 \mathrm{H},{ }^{3} \mathrm{~J}_{\mathrm{a}^{\prime}, \mathrm{b}}=5.0 \mathrm{~Hz},{ }^{2} \mathrm{~J}_{\mathrm{a}, \mathrm{a}^{\prime}}=10.6 \mathrm{~Hz}, \mathrm{Ha}^{\prime}\right), 3.69\left(\mathrm{t}, 2 \mathrm{H},{ }^{3} \mathrm{~J}=\right.$ $5.1 \mathrm{~Hz}, \mathrm{Hb}), 3.64\left(\mathrm{dd}, 1 \mathrm{H},{ }^{3} J_{3,4}=3.7 \mathrm{~Hz},{ }^{3} J_{4,5}=5.7 \mathrm{~Hz}, \mathrm{H} 4\right)$, $1.37-1.80$ ( $\mathrm{m}, 20 \mathrm{H}$, protons of cyclohexylidene groups); ${ }^{13} \mathrm{C}-\mathrm{NMR}\left(75 \mathrm{MHz}, \mathrm{CDCl}_{3}\right) \delta 113.0,109.2,106.4,84.5$, 80.2, 79.0, 72.7, 69.9, 66.3, 65.9, 36.2, 35.5, 34.6, 34.0, 25.0, 24.9, 23.9, 23.8, 23.7, 23.5; FT-IR ( $\mathrm{cm}^{-1}$, neat) 1214 , 1167 (ethers); $[\alpha]_{\mathrm{D}}-15^{\circ}(c=0.1$, chloroform); Anal. Calcd. for $\mathrm{C}_{40} \mathrm{H}_{62} \mathrm{O}_{13}, \mathrm{C}$ 63.98, H 8.32. Found C 63.63, H 8.26 .

The following are the physical and spectral properties of 4: colorless syrup; FABMS, $m / z 817(\mathrm{M}+$ $\mathrm{Na})^{+} ;{ }^{1} \mathrm{H}-\mathrm{NMR}\left(300 \mathrm{MHz}, \mathrm{CDCl}_{3}\right) \delta 4.77\left(\mathrm{~d}, 1 \mathrm{H},{ }^{3} J_{1,2}=3.5\right.$ $\mathrm{Hz}, \mathrm{H} 1), 4.67\left(\mathrm{dd}, 1 \mathrm{H},{ }^{3} J_{2,3}=6.0 \mathrm{~Hz},{ }^{3} J_{3,4}=3.7 \mathrm{~Hz}, \mathrm{H} 3\right)$, $4.61\left(\mathrm{dd}, 1 \mathrm{H},{ }^{3} J_{1,2}=3.5 \mathrm{~Hz},{ }^{3} J_{2,3}=6.0 \mathrm{~Hz}, \mathrm{H} 2\right), 4.43(\mathrm{dt}, 1 \mathrm{H}$, $\left.{ }^{3} J_{4,5}={ }^{3} J_{5,6}=6.0 \mathrm{~Hz}, \mathrm{H} 5\right), 4.05\left(\mathrm{~d}, 2 \mathrm{H},{ }^{3} J_{5,6}=6.0 \mathrm{~Hz}, \mathrm{H} 6\right)$, $3.93\left(\mathrm{dt}, 1 \mathrm{H},{ }^{3} J_{\mathrm{a}, \mathrm{b}}=5.0 \mathrm{~Hz},{ }^{2} J_{\mathrm{a}, \mathrm{a}^{\prime}}=10.8 \mathrm{~Hz}, \mathrm{Ha}\right), 3.78(\mathrm{dt}$, $\left.1 \mathrm{H},{ }^{3} J_{\mathrm{a}^{\prime}, \mathrm{b}}=5.5 \mathrm{~Hz},{ }^{2} J_{\mathrm{a}, \mathrm{a}^{\prime}}=10.8 \mathrm{~Hz}, \mathrm{Ha}^{\prime}\right), 3.70\left(\mathrm{dt}, 2 \mathrm{H},{ }^{3} J_{\mathrm{a}, \mathrm{b}}\right.$ $\left.=5.0 \mathrm{~Hz},{ }^{3} \mathrm{~J}_{\mathrm{a}^{\prime}, \mathrm{b}}=5.5 \mathrm{~Hz}, \mathrm{Hb}\right), 3.70-3.67$ (m, 1H, H4), 3.64 (s, 2H, Hc), 1.43-1.80 (m, 20H, protons of cyclohexylidene groups); ${ }^{13} \mathrm{C}-\mathrm{NMR}\left(75 \mathrm{MHz}, \mathrm{CDCl}_{3}\right) \delta 113.1,109.3$, 106.5, 84.5, 80.3, 79.0, 72.8, 70.4, 70.1, 66.3, 66.0, 36.2, 35.5, 34.6, 34.0, 25.1, 25.0, 23.9, 23.8, 23.7, 23.6; FT-IR $\left(\mathrm{cm}^{-1}\right.$, neat) 1213,1165 (ethers); $[\alpha]_{\mathrm{D}}-11^{\circ}(c=0.1$, chloroform); Anal. Calcd. for $\mathrm{C}_{42} \mathrm{H}_{66} \mathrm{O}_{14}, \mathrm{C}$ 63.46, $\mathrm{H}$ 8.37. Found C 63.14, H 8.34.

\subsection{Preparation of sample solution for the FABMS/} EL guest method

A sample solution was prepared by mixing three solutions under the following conditions: (1) $10 \mu \mathrm{L}$ of a $0.67 \mathrm{M}$ solution of an equimolar mixture of unlabeled $(R)$ and deuterium-labeled $(S)$-guests $\left(\left[\mathrm{G}_{R}{ }^{+}\right]_{0}=\left[\mathrm{G}_{S-d_{n}}{ }^{+}\right]_{0}\right.$ $=0.33 \mathrm{M}$ ) in methanol, (2) $5 \mu \mathrm{L}$ of a $0.20 \mathrm{M}$ host $(\mathrm{H})$ solution in chloroform, and (3) $15 \mu \mathrm{L}$ of NBA. The prepared solution was homogenized with a vibrator and made to stand overnight. FABMS measurements were performed by depositing a $1 \mu \mathrm{L}$ aliquot of the mixed solution on a FAB probe tip. After the evaporation of methanol and chloroform in the ion source, the concentrations in NBA were calculated as $[\mathrm{H}]_{0}=0.0167$ $\mathrm{M},\left[\mathrm{G}_{R}{ }^{+}\right]_{0}=\left[\mathrm{G}_{S-d_{n}}{ }^{+}\right]_{0}=0.0500 \mathrm{M},[\mathrm{H}]_{0} /\left[\mathrm{G}_{R}{ }^{+}\right]_{0} /\left[\mathrm{G}_{S-d_{n}}{ }^{+}\right]_{0}=$ $1: 3: 3$. The accuracy of the $1 / 1$ equivalent concentration of $(R)$ and $(S)$-enantiomers was confirmed by (1) determining whether the relative intensity $\left[I\left(\mathrm{H}+\mathrm{G}_{R}\right)^{+} /\right.$ $\left.I\left(\mathrm{H}+\mathrm{G}_{S-d_{n}}\right)^{+}=I_{R} / I_{S-d_{n}}\right]$ values with a host of 18-crown-6, which is an achiral host, were experimentally obtained as unity (1.00 \pm 0.03$)$; (2) determining whether the rela- tive peak areas were observed as unity in highperformance liquid chromatography (column, Daicel Crownpak CR; eluate, aqueous perchloric acid, pH 1.5) (Phe-O- ${ }^{i} \mathrm{Pr}^{+}$and Pgly-O- ${ }^{i} \mathrm{Pr}^{+}$cases).

The FAB mass spectra were accumulated from the 10 th to 30 th scan (21 scans). The data comprises the average values of three measurements.

\subsection{NMR experiments}

The stoichiometry of complexation of host 3 with an ammonium ion guest (counter anion=thiocyanate) in acetone- $d_{6}$ at $25^{\circ} \mathrm{C}$ was examined by Job's plot using a high concentration solutions $\left([\mathrm{H}]_{0}+[\mathrm{G}]_{0}=0.0622\right.$ M). ${ }^{23), 24)}$ The $\Delta \delta_{\mathrm{H}} \cdot[\mathrm{H}]_{0}$ values are plotted against the mole fraction $(\chi)$ of the host in Fig. 1, where $\Delta \delta_{\mathrm{H}}$ is the induced shift $(\mathrm{Hz})$ of signal $\mathrm{H} 1$, and $[\mathrm{H}]_{0}$ is the total host concentration. For exclusive formation of a $1: 1 \mathrm{com}-$ plex, the plot should peak at $\chi=0.5$. Although the induced shifts of the host were too small to fit the simulation curve accurately, the peak at $\chi=0.5$ is recognized in the plots. In FAB mass spectrometry under the conditions described in the previous section, only a $1: 1$ complex ion of host 3 with ammonium ion was observed. Therefore, the stoichiometry between host 3 and the ammonium ion guest is confirmed as 1 : 1 , at least in an acetone solution.

An ammonium thiocyanate solution in acetone- $d_{6}$ was added stepwise into the host solution in acetone- $d_{6}$ in an NMR tube maintained at $25^{\circ} \mathrm{C}$ until the addition results in zero or negligible shift, and then the induced shifts were measured. The association constants were determined by a nonlinear method for the $1: 1$ complexation on the basis of the induced shifts and initial concentration of the host and guest $\left([\mathrm{H}]_{0}\right.$ and $\left.\left[\mathrm{G}^{+}\right]_{0}\right){ }^{23)-25)}$ Ammonium thiocyanate was chosen for its good solubility in acetone.

Host 3 with ammonium thiocyanate provides a typical example. Ammonium thiocyanate solution in acetone- $d_{6}(x \mu \mathrm{L}, 0.551 \mathrm{M} ; x=2,4,8,16,30,40,60,80$, $100,150,200,300$, and 400 ; total $1,390 \mu \mathrm{L}$ ) was added to $0.6 \mathrm{~mL}$ of a $3.44 \times 10^{-3} \mathrm{M}$ host 3 solution in acetone-

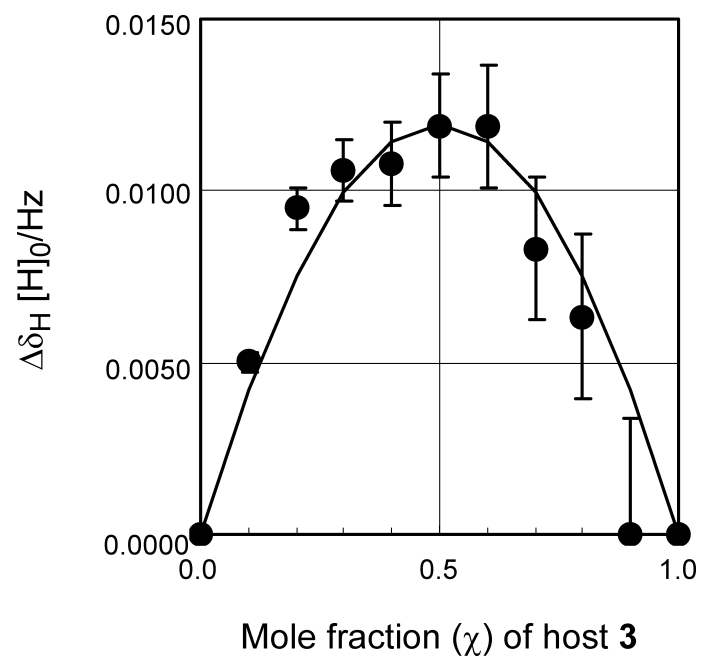

Fig. 1. Job's plot of complexation between host 3 and an ammonium ion guest in acetone- $d_{6}$ at $25^{\circ} \mathrm{C}$. $\left([\mathrm{H}]_{0}+[\mathrm{G}]_{0}\right)=0.622 \mathrm{M} . \quad \Delta \delta_{\mathrm{H}}$ is the induced shift $(\mathrm{Hz})$ of $\mathrm{H} 1$ by adding the guest. 
Table 1. ${ }^{1} \mathrm{H}-\mathrm{NMR}(300 \mathrm{MHz})$ Induced Shifts $(\mathrm{Hz})$ of Host 3 by Adding Ammonium Thiocyanate in Acetone- $d_{6}$ at $25^{\circ} \mathrm{C}$

\begin{tabular}{crrrrrrr}
\hline$[\mathrm{G}]_{0} /[\mathrm{H}]_{0}$ & \multicolumn{1}{c}{$\mathrm{H} 1$} & \multicolumn{1}{c}{$\mathrm{H} 2$} & $\mathrm{H} 4$ & $\mathrm{H} 5$ & $\mathrm{Ha}$ & \multicolumn{1}{c}{$\mathrm{Ha}^{\prime}$} & \multicolumn{1}{c}{$\mathrm{Hb}$} \\
\hline 0.535 & 1.10 & 1.28 & 0.26 & 0.18 & 1.01 & 0.73 & 0.92 \\
1.60 & 2.75 & 2.93 & 0.44 & 0.55 & 2.84 & 2.75 & 2.38 \\
3.74 & 5.32 & 5.69 & 0.88 & 0.92 & 5.60 & 5.69 & 4.59 \\
8.02 & 9.54 & 10.27 & 1.61 & 2.02 & 9.81 & 10.64 & 8.25 \\
16.0 & 15.22 & 16.14 & 2.60 & 3.12 & 15.68 & 16.87 & 13.20 \\
26.7 & 20.72 & 21.09 & 3.56 & 4.40 & 21.00 & 22.56 & 16.87 \\
42.8 & 25.28 & 25.22 & 4.40 & 5.45 & 25.35 & 27.47 & 20.26 \\
64.2 & 29.16 & 28.53 & 5.10 & 6.44 & 28.86 & 31.20 & 22.68 \\
90.9 & 31.83 & 30.73 & 5.61 & 7.06 & 30.99 & 33.92 & 24.41 \\
131 & 34.20 & 32.74 & 6.14 & 7.69 & 33.32 & 35.53 & 25.85 \\
184 & 36.11 & 34.13 & 6.39 & 8.18 & 34.95 & 38.07 & 26.96 \\
265 & 37.45 & 35.21 & 6.70 & 8.50 & 35.94 & 39.08 & 27.75 \\
372 & 38.48 & 35.98 & 6.90 & 8.78 & 36.83 & 40.02 & 28.33 \\
\hline
\end{tabular}

The shift values are adopted from one of three experiments. The final percentage of the associated host was calculated as $79 \%$.

$d_{6}$, and the NMR spectra of these solutions were measured. The concentration ratios $[\mathrm{G}]_{0} /[\mathrm{H}]_{0}$ of the guest and host (after the addition) for the corresponding $x$ values were $0.535,1.60,3.74,8.02,16.04,26.7,42.8,64.2$, $90.9,131,184,265$, and 372 . The association constant $(K)$ was determined using a typical nonlinear method ( $1: 1$ simulation). The calculated $K$ values were $9.1 \mathrm{M}^{-1}$ (H1), 11.7 $\mathrm{M}^{-1}$ (H2), 8.0 M-1 (H4), 7.5 $\mathrm{M}^{-1}$ (H5), 10.7 $\mathrm{M}^{-1}$ (Ha), 10.6 $\mathrm{M}^{-1}\left(\mathrm{Ha}^{\prime}\right)$, and $12.6 \mathrm{M}^{-1}(\mathrm{Hb})$. The monitored proton signals are shown above in parentheses. The shift change of each signal induced by adding the guest solution in acetone- $d_{6}$ is summarized in Table 1 . The averaged value was $(1.0 \pm 0.2) \times 10 \mathrm{M}^{-1}$. The NMR titration experiments were performed three times for each host. The final $K$ value of complexation between host 3 and the ammonium ion (counteranion= thiocyanate) was calculated to be $(1.0 \pm 0.5) \times 10 \mathrm{M}^{-1}$. The limiting shifts induced by complexation, which represent the shifts of the 100\% complexing host, were calculated on the basis of the induced shifts for certain concentrations of the host and guest, and the $K$ values.

\subsection{UV-VIS experiments}

The bathochromic shifts of $\lambda_{\max }$ of the given ammonium picrates caused by adding hosts $(\mathbf{2} \mathbf{a}, \mathbf{3}$, and $\mathbf{4})$ in chloroform or chloroform/THF $(1: 1, \mathrm{v} / \mathrm{v})$ were determined by gradually adding a chiral host to a $c a .5 \times$ $10^{-5} \mathrm{M}$ solution of ammonium picrate or $(R)$-Trp-O- ${ }^{i} \mathrm{Pr}^{+}$ picrate stirred magnetically in a cell until either no shift was observed or the isosbestic relationship disappeared. For host $\mathbf{2 a}$, at that point the concentration ratio $[\mathrm{H}]_{0} /[\mathrm{G}]_{0}$ was $c a$. $70\left(K=2,200 \mathrm{M}^{-1}\right.$, the percentage of th associated host is estimated at 45\%). ${ }^{11)} \mathrm{A}$ new $\lambda_{\max }$ was then determined from the final UV-VIS spectrum. For hosts 3 and 4, they were added to the guest solution until $[\mathrm{H}]_{0} /[\mathrm{G}]_{0}=c a .900$. However, bathochromic shifts were not observed under these conditions. The bathochromic shifts were so small that the $K$ values were not determined. To maintain the temperature of the cell, water regulated at $25^{\circ} \mathrm{C}$ in a NESLAB endocal refrigerated circulating bath was allowed to flow into the circulating cell holder. The light sources were $\mathrm{D}_{2}$ and $\mathrm{W}$ lamps. The scan range was $280-500 \mathrm{~nm}$ and the scan speed was $120 \mathrm{~nm}$ $\min ^{-1}$.

\section{Results and Discussion}

\subsection{Quantitative evaluation of chiral discrimina- tion ability by the FABMS/EL guest method}

The FAB mass spectra of three component sample solutions, including a chiral host $(\mathrm{H})$ and equivalent unlabeled $(R)$ - and deuterium-labeled $(S)$-guests $\left(\mathrm{G}_{R}{ }^{+}\right.$ and $\mathrm{G}_{S-\mathrm{dn}}{ }^{+}$), were measured, and two resulting diastereomeric complex ions, $\left(\mathrm{H}+\mathrm{G}_{R}\right)^{+}$and $\left(\mathrm{H}+\mathrm{G}_{S-d_{n}}\right)^{+}$, were observed in all cases. The typical mass spectra are shown in Fig. 2. The relative peak intensity of the complex ions $\left[I\left(\mathrm{H}+\mathrm{G}_{R}\right)^{+} / I\left(\mathrm{H}+\mathrm{G}_{S-d_{n}}\right)^{+}=I_{R} / I_{S-d_{n}}\right.$ value $]$ is a measure of chiral discrimination ability, and is approximately equal to the association constant ratio $\left(K_{R} / K_{S}\right)$ in the complexation equilibrium systems. ${ }^{4), 5)}$ The $I_{R} / I_{S \text {-dn }}$ values of hosts $2 \mathrm{a}, 3$, and 4 toward protonated amino acid isopropyl ester guests are summarized in Table 2.

Host 3 showed good chiral discrimination toward several guests (Val-O- ${ }^{i} \mathrm{Pr}^{+}$, Met-O- ${ }^{i} \mathrm{Pr}^{+}$, Phe-O- ${ }^{i} \mathrm{Pr}^{+}$, and Pgly-O- $\left.{ }^{i} \mathrm{Pr}^{+}\right)$. However, the $I_{R} / I_{S-d_{n}}$ values of 3 for Pro- ${ }^{-i} \mathrm{Pr}^{+}$and Ala- $\mathrm{O}^{-i} \mathrm{Pr}^{+}$approached unity, in contrast to those of $2 \mathbf{a}$. The enantiomer preferences of 3 did not agree with those of $\mathbf{2 a}$; for example, $\mathbf{2} \mathbf{a}$ and $\mathbf{3}$ showed $(S)$ - and $(R)$-selectivity for $\mathrm{Val}-\mathrm{O}-{ }^{i} \mathrm{Pr}^{+}$, respectively. This suggests that the complex structure of 3 with the guest is different from that of 2 . On the other hand, the $I_{R} / I_{S-d_{n}}$ values of 4 were determined to be almost unity, and the enantioselectivity was very small. Although the partial structures relating to the steric effects of hosts 3 and 4 (the 2,3:5,6-di- $O$-cyclohexylidene- $\beta$-D-mannofuranose moiety) were identical, the enantioselectivity of 3 and $\mathbf{4}$ differed significantly. To clarify the effect of the length of the oxyethylene chain moiety on chiral discrimination, the structural differences of the host-guest complex ions must be examined.

\subsection{Limiting shifts of complexation with ammoni- um ions in NMR}

Host 3 showed specific shifts induced by complexing with the ammonium ion (Fig. 3). The limiting shifts and the association constants $(K)$, which were calculated from the induced shifts, and the concentrations of the host and guest, are summarized in Table 3.

The $K$ value of host 3 was smaller than that of 4 , possibly because the number of oxygen atoms contributing to the binding with cation in host 3 was smaller than that in 4 . With regard to the limiting shifts, $\mathrm{H} 1, \mathrm{H} 2$, and the protons of the oxyethylene chain moiety, such as $\mathrm{Ha}, \mathrm{Ha}^{\prime}$, and $\mathrm{Hb}$, of both hosts 3 and 4 showed large shifts, suggesting that these protons surround the cation guest. Therefore, the sequence of the oxygen atoms, including $\mathrm{O} 1, \mathrm{O} 2$, and the oxygen atoms of the oxyethylene chain, is considered to be the binding site to the cation moiety of the guest by chargedipole electrostatic intermolecular interaction (Fig. 4).

3.3 Bathochromic shifts of $\lambda_{\max }$ of ammonium picrate in UV-VIS spectra

The use of the picrate anion probe is a very useful technique for observing the complexation between 
(a)

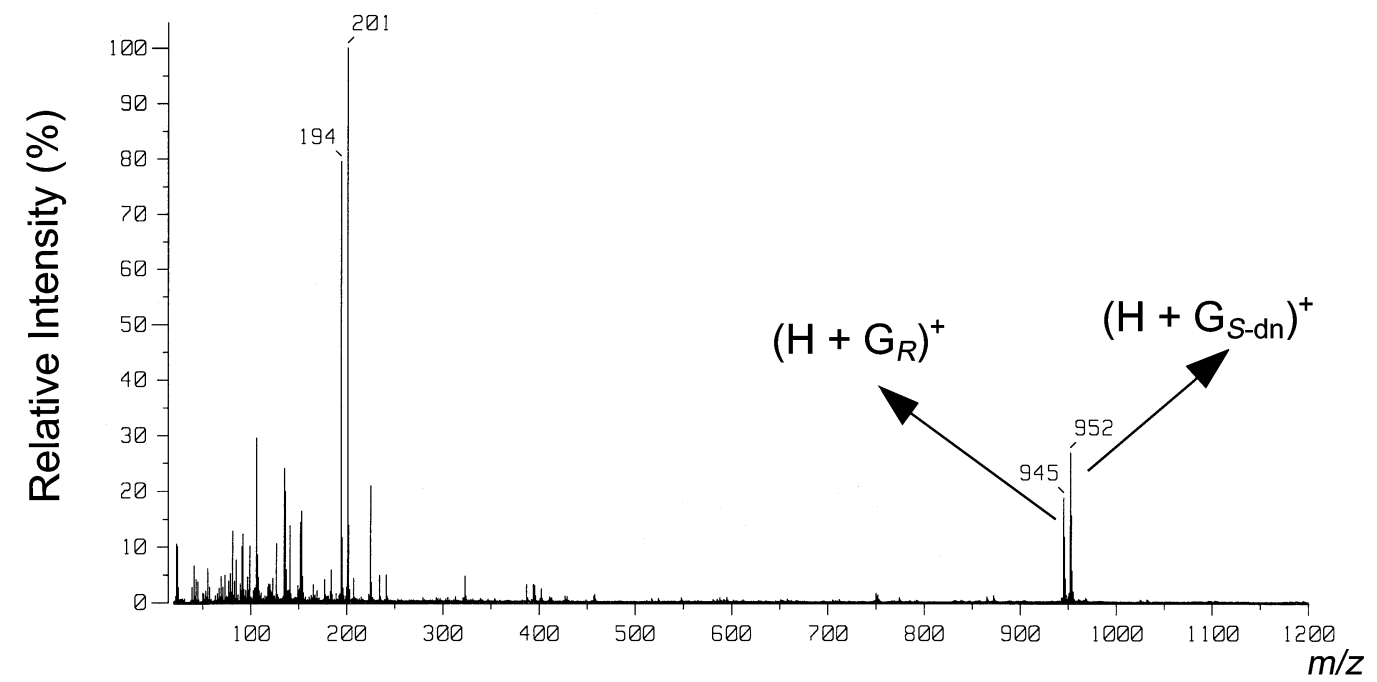

(b)

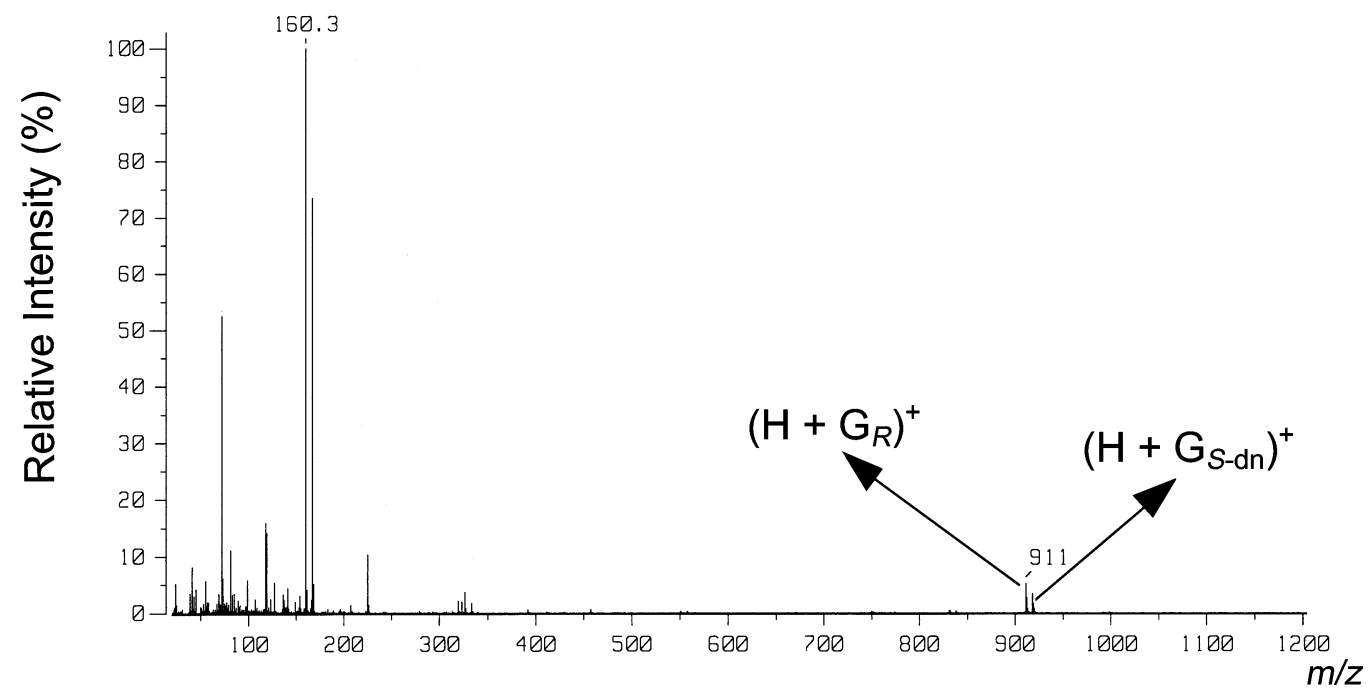

(c)

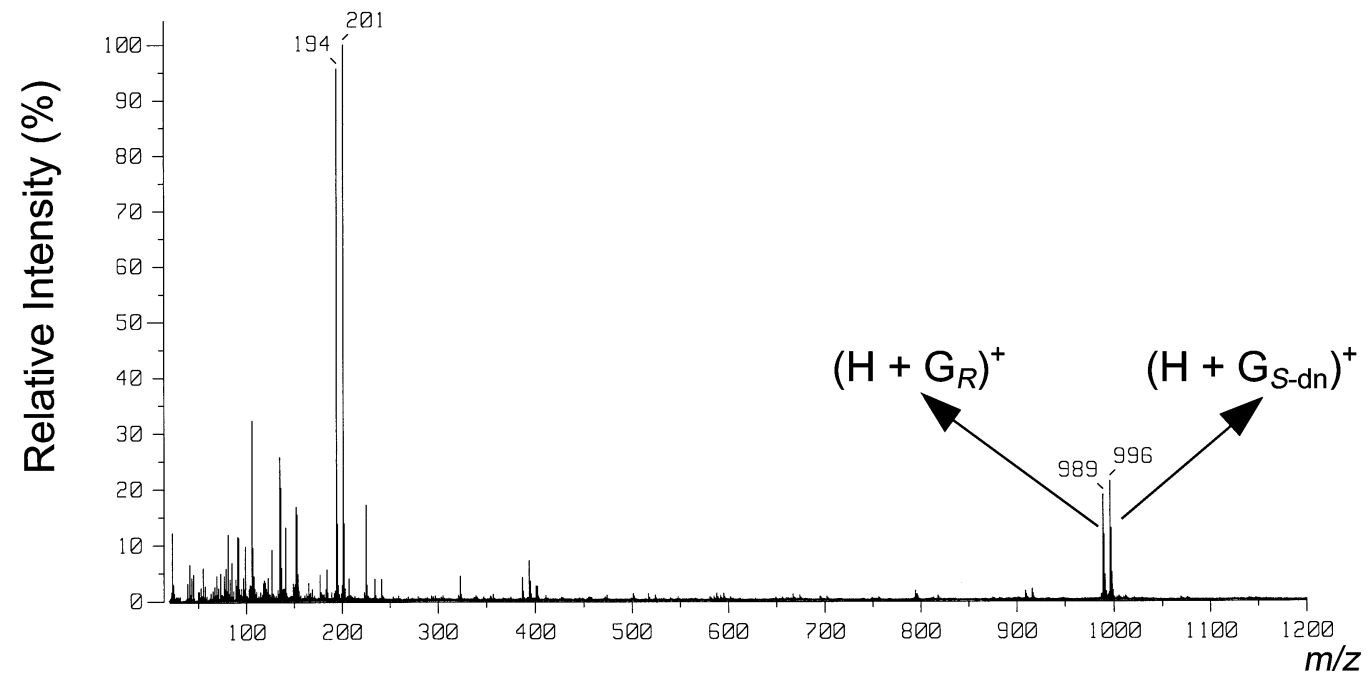

Fig. 2. Typical FAB mass spectra in the FABMS/EL guest method. (a) Host, 3; guest, $\mathrm{Pgly}-\mathrm{O}-{ }^{i} \mathrm{Pr}^{+} ;\left(\mathrm{H}+\mathrm{G}_{R}\right)^{+}, m / z 945$; $\left(\mathrm{H}+\mathrm{G}_{S-d_{n}}\right)^{+}, m / z$ 952. (b) Host, 3; guest, Val-O- ${ }^{i} \operatorname{Pr}^{+} ;\left(\mathrm{H}+\mathrm{G}_{R}\right)^{+}, m / z$ 911; $\left(\mathrm{H}+\mathrm{G}_{S-d_{n}}\right)^{+}, m / z$ 918. (a) Host, 4; guest, Pgly-O- ${ }^{i} \operatorname{Pr}^{+} ;\left(\mathrm{H}+\mathrm{G}_{R}\right)^{+}, m / z$ 989; $\left(\mathrm{H}+\mathrm{G}_{s-d_{n}}\right)^{+}, m / z$ 996. 3-Nitrobenzyl alcohol was used as the matrix. The counter anion was chloride $\left(\mathrm{Cl}^{-}\right)$.

spectrometrically inactive hosts and cation guests in the UV-VIS region by means of UV-VIS spectrometry. ${ }^{26), 27)}$ In general, a cation-picrate anion pair, which forms a tight ion pair in a low-polarity solvent, is separated by complexing with a host. As a result of the decrease in the electrostatic cation-anion interaction, a bathochromic shift is observed, because the $\pi$-electron system in the picrate anion is more delocalized than 
Table 2. $I_{R} / I_{S-d_{n}}$ Values of Chiral Hosts 2a, 3, and 4 toward Protonated Amino Acid Isopropyl Ester Guests in the FABMS/EL Guest Method

\begin{tabular}{|c|c|c|c|c|c|c|c|}
\hline \multirow{2}{*}{ Host } & \multicolumn{7}{|c|}{ Guest } \\
\hline & Ala-O- ${ }^{i} \operatorname{Pr}^{+}$ & Val-O- ${ }^{i} \mathrm{Pr}^{+}$ & Met-O- ${ }^{i} \mathrm{Pr}^{+}$ & Pro-O- ${ }^{i} \mathrm{Pr}^{+}$ & Phe-O- ${ }^{i} \mathrm{Pr}^{+}$ & Trp-O- ${ }^{i} \mathrm{Pr}^{+}$ & Pgly-O- ${ }^{i} \mathrm{Pr}^{+}$ \\
\hline $2 a$ & 1.43 & 0.85 & 1.33 & 1.98 & 1.78 & 2.64 & 0.76 \\
\hline 3 & 0.84 & 1.48 & 0.76 & 0.89 & 0.78 & 1.53 & 0.70 \\
\hline 4 & 1.02 & 1.07 & 1.01 & 0.94 & 1.01 & 0.98 & 0.89 \\
\hline
\end{tabular}

The $I_{R} / I_{S-d_{n}}$ values of complex of 18-crown-6 with the above guests were unity (1.00 \pm 0.03$)$. 3-Nitrobenzyl alcohol was used as the matrix.

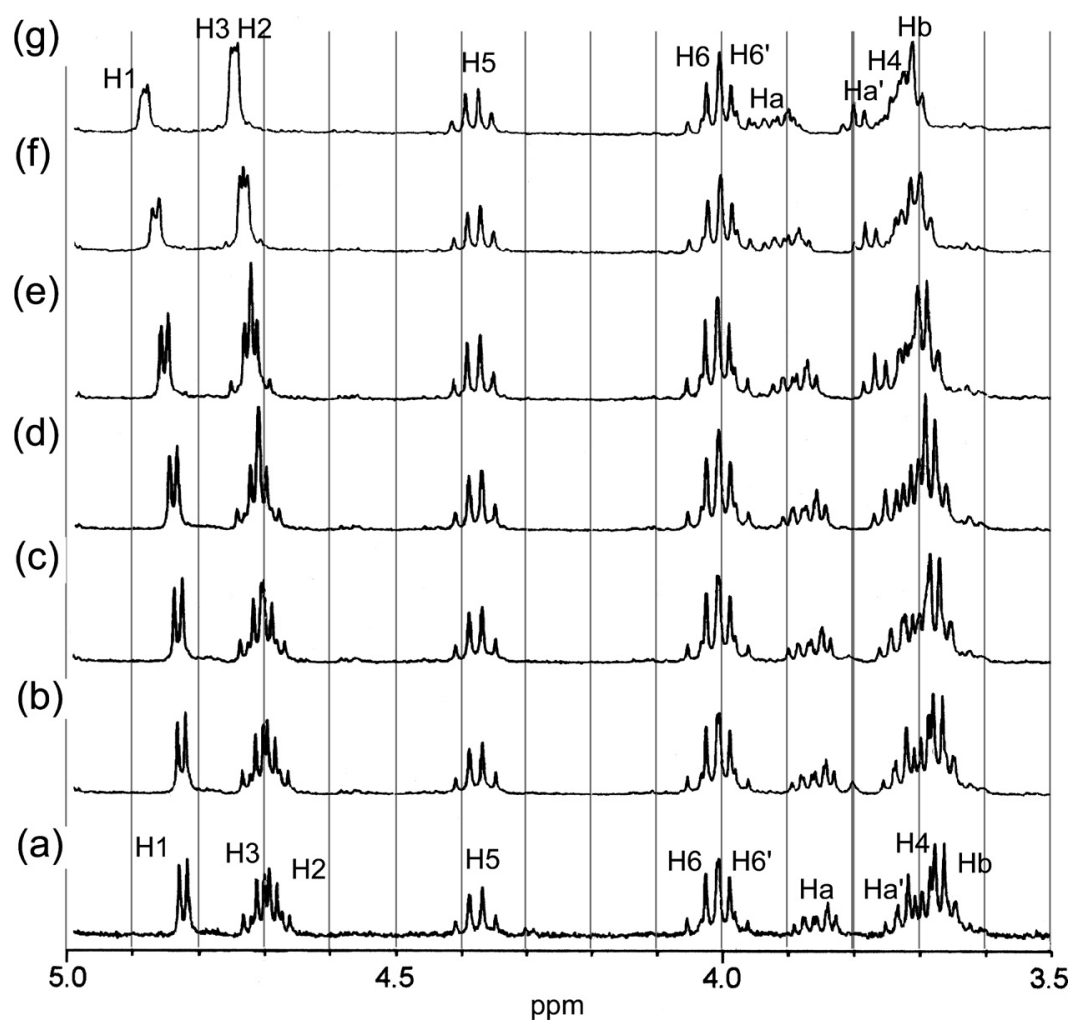

Fig. 3. ${ }^{1} \mathrm{H}$-NMR spectral changes of host 3 in acetone- $d_{6}$ with the addition of ammonium thiocyanate at $25^{\circ} \mathrm{C}\left([\mathrm{H}]_{0}=3.44\right.$ $\times 10^{-3} \mathrm{M}$ ). The concentration ratio of $[\mathrm{G}]_{0} /[\mathrm{H}]_{0}$ : (a) 0 , (b) 1.1, (c) 2.5, (d) 5.3, (e) 11, (f) 20, (g) 32 .

Table 3. Limiting Shifts of Chiral Hosts 3 and 4 Induced by Complexation with Ammonium Ion (Counter Ion: Thiocyanate) in ${ }^{1} \mathrm{H}-\mathrm{NMR}$ and the Association Constants $(K)$ in Acetone- $d_{6}$ at $25^{\circ} \mathrm{C}$

\begin{tabular}{|c|c|c|c|c|c|c|c|c|c|c|c|c|}
\hline \multirow{2}{*}{ Host } & \multicolumn{11}{|c|}{ Limiting shifts (ppm) } & \multirow{2}{*}{$K\left(\mathrm{M}^{-1}\right)$} \\
\hline & $\mathrm{H} 1$ & $\mathrm{H} 2$ & H3 & $\mathrm{H} 4$ & H5 & H6 & $\mathrm{H}^{\prime}$ & $\mathrm{Ha}$ & $\mathrm{Ha}^{\prime}$ & $\mathrm{Hb}$ & $\mathrm{Hc}$ & \\
\hline 3 & 0.16 & 0.16 & 0.11 & 0.03 & 0.03 & 0.02 & 0.02 & 0.16 & 0.17 & 0.13 & - & $(1.0 \pm 0.5) \times 10$ \\
\hline 4 & 0.16 & 0.15 & 0.11 & 0.04 & 0.02 & 0.02 & 0.01 & 0.13 & 0.16 & 0.11 & 0.11 & $(2.8 \pm 0.4) \times 10$ \\
\hline
\end{tabular}

(a)

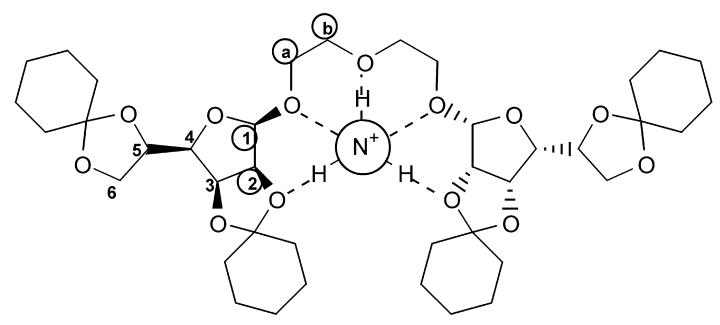

(b)

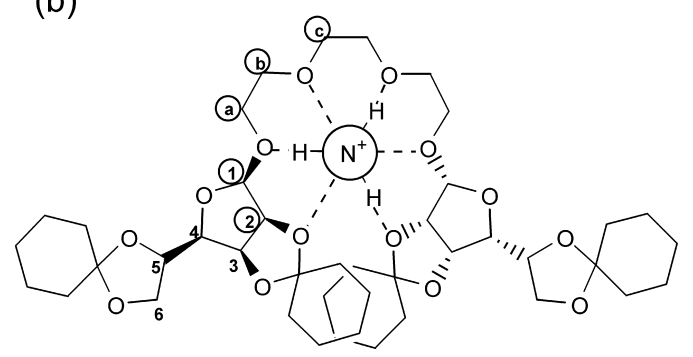

Fig. 4. Binding sites of (a) host 3 and (b) host 4 for an ammonium ion determined based on the specific limiting shifts in ${ }^{1} \mathrm{H}-\mathrm{NMR}$. The positions of the proton showing large shifts are indicated by the circled numbers. 
that before complexation. The bathochromic shifts of $\lambda_{\max }$ of picrate salts with an ammonium ion and with Trp-O- ${ }^{i} \operatorname{Pr}^{+}$guest by the addition of hosts $2 \mathrm{a}, 3$, and 4 are summarized in Table 4.

In case of $\mathbf{2 a}$, both picrate salts showed bathochromic shifts, suggesting that the guest cation-picrate anion pair became a separated ion pair by complexation with 2a. On the other hand, bathochromic shifts of the guest picrates were not observed from the addition of hosts 3 and 4. The bathochromic shift depends on the average distance between the cation and the picrate anion. The factors causing a bathochromic shift are (1) the proportion of the complexing guest in the system and (2) the degree of separation between the cation and the picrate anion, which depends on the structure of the complex. The $K$ values of hosts 3 and 4 with ammonium ion guests in $\mathrm{CHCl}_{3}$ or $\mathrm{CHCl}_{3}$ / THF are larger than those in

Table 4. Bathochromic Shifts of $\lambda_{\max }$ of Picrate Anion $\left(\mathrm{Pic}^{-}\right)$of Guest Salts $\left(\mathrm{G}^{+} \mathrm{Pic}^{-}\right)$Induced by Complexation with Chiral Hosts 2a, 3, and 4 at $25^{\circ} \mathrm{C}$ in UV-VIS

\begin{tabular}{|c|c|c|c|}
\hline Host & Guest & Solvent & Bathochromic shift (nm) \\
\hline $2 a$ & $\mathrm{NH}_{4}^{+}$ & $\mathrm{CHCl}_{3} / \mathrm{THF}$ & $7^{a}$ \\
\hline $2 a$ & $(R)-$ Trp-O- ${ }^{i} \mathrm{Pr}^{+}$ & $\mathrm{CHCl}_{3}$ & $4^{a}$ \\
\hline 3 & $\mathrm{NH}_{4}^{+}$ & $\mathrm{CHCl}_{3} / \mathrm{THF}$ & $0^{b}$ \\
\hline 3 & $(R)-$ Trp-O- ${ }^{i} \operatorname{Pr}^{+}$ & $\mathrm{CHCl}_{3}$ & $0^{b}$ \\
\hline 4 & $\mathrm{NH}_{4}^{+}$ & $\mathrm{CHCl}_{3} / \mathrm{THF}$ & $0^{b}$ \\
\hline 4 & $(R)$-Trp-O- ${ }^{i} \mathrm{Pr}^{+}$ & $\mathrm{CHCl}_{3}$ & $0^{b}$ \\
\hline
\end{tabular}

$[\mathrm{H}]_{0}=c a . \quad 5 \times 10^{-5} \mathrm{M} . \quad{ }^{a}[\mathrm{H}]_{0} /\left[\mathrm{G}^{+}\right]_{0}=70 . \quad{ }^{b}[\mathrm{H}]_{0} /\left[\mathrm{G}^{+}\right]_{0}=900$. The ratio of $\mathrm{CHCl}_{3} / \mathrm{THF}$ was $1: 1(\mathrm{v} / \mathrm{v})$. The wavelengths $\left(\lambda_{\max }\right)$ of ammonium picrate and $(R)-\operatorname{Trp}-\mathrm{O}-{ }^{i} \mathrm{Pr}^{+}\left(\mathrm{Pic}^{-}\right)$were 353 and $347 \mathrm{~nm}$, respectively. more polar solvents such as acetone, since the driving force of complexation is the charge-dipole electrostatic intermolecular interaction. Indeed, the $K$ values between $\mathbf{2} \mathbf{a}$ and the organic ammonium ion guests in $\mathrm{THF} /$ chloroform or chloroform were larger than those in acetone, and the bathochromic shifts were observed under the conditions of $[\mathrm{H}]_{0} /[\mathrm{G}]_{0}=c a$. 70 (Table 4). The $K$ values between host $\mathbf{2} \mathbf{a}$ and the ammonium ion are reported to be $15 \mathrm{M}^{-1}$ in acetone- $d_{6}$ at $25^{\circ} \mathrm{C}$. As described above, the $K$ values of hosts 3 and 4 with the ammonium ion in acetone- $d_{6}$ were 10 and $28 \mathrm{M}^{-1}$, respectively. The percentage of the associated host for the total host 3 or 4 in the solution under the same concentration conditions would not differ from that of host 2a. Therefore, the structural factor is considered to be the main reason for the absence of bathochromic shifts in UV-VIS.

\subsection{Complex structures of hosts 3 and 4 with chiral ammonium ions}

The binding sites of hosts 3 and 4 were elucidated on the basis of the limiting shifts in NMR, as shown in Fig. 4. The hosts are considered to show the pseudo-ring conformation in complex with an unsubstituted ammonium ion guest. However, the results of UV-VIS experiments suggest that there is a large open space around the cation guest in the host-guest complex. Thus, the packing between the cation guest and the hosts may be loose, presumably due to the steric repulsion of the cyclohexylidene groups, which approach each other by the conformational change of the host to the pseudoring structure in the complexation. Indeed, the $K$ value of $2 \mathbf{a}$ with an ammonium ion $\left(15 \mathrm{M}^{-1}\right)$ is larger than that of $3\left(10 \mathrm{M}^{-1}\right)$.

The structures of the complexes of hosts 3 and 4 are illustrated in Scheme 2. As described above, the ammo-
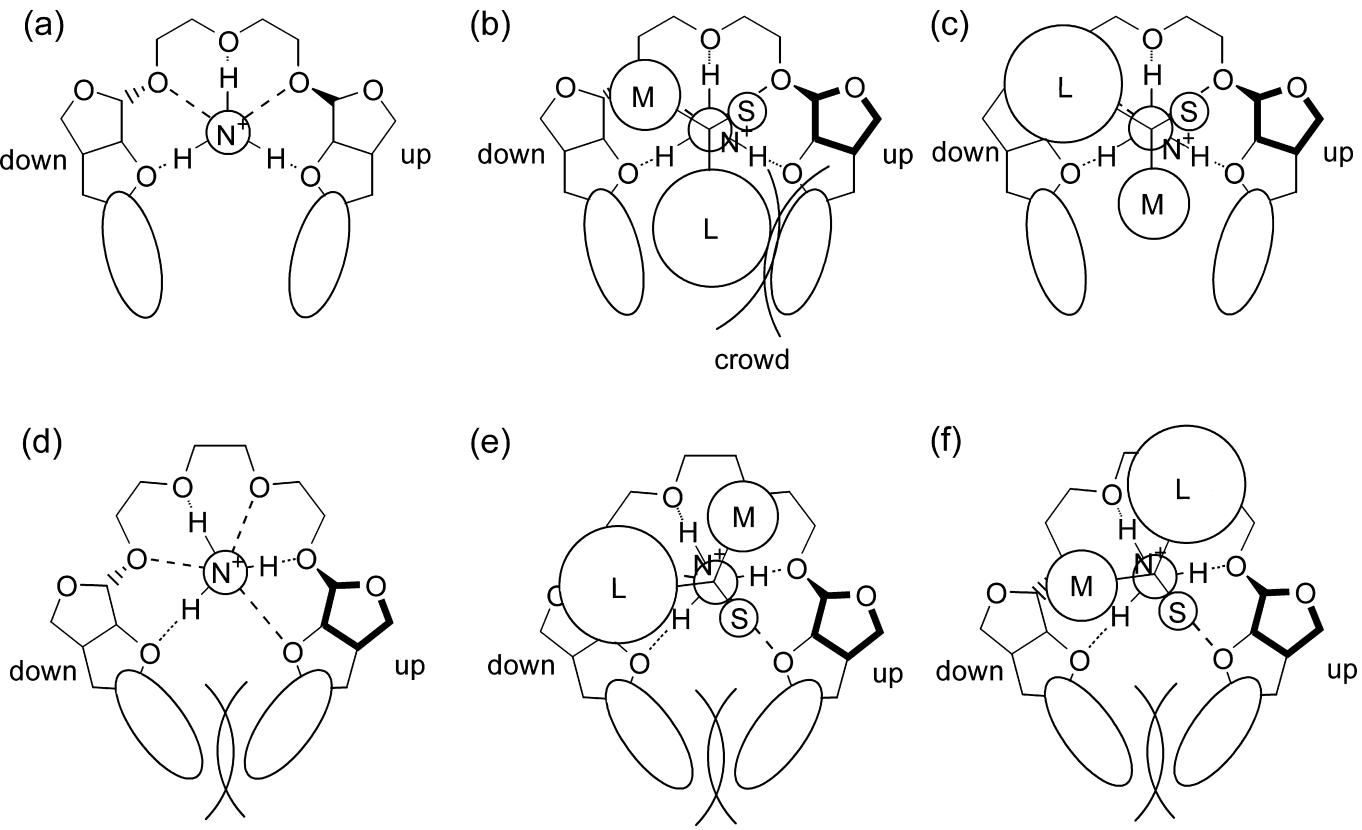

Scheme 2. Chiral recognition mechanisms of hosts 3 and 4 . Host, guest: (a) 3, ammonium ion; (b) 3, one of the enantiomeric ammonium ion guests; (c) 3, another enantiomeric guest; (d) 4, ammonium ion; (e) 4, one of the enantiomeric ammonium ion guest; and (f) 4, another enantiomeric guest. The positions of the mannofuranose moieties for the pseudo-ring plane are shown by "up" or "down." For host 3, the steric effect differs with each enantiomer of the organic ammonium ion guest. For host 4, the differences in the steric effects are negligible. 
nium moiety of the guests is located at the binding site, which consists of the oxygen atoms of the oxyethylene chain and $\mathrm{O} 1$ of the mannofuranose moieties (Schemes 2(a) and (d)). In Schemes 2 (b), (c), (e), and (f), the complex ions of the hosts with chiral ammonium ion guests have three substituent groups of the $\alpha$-carbon. The substituent groups are classified into large (L), middle $(\mathrm{M})$, and small $(\mathrm{S})$, depending on size. In host 3 , the steric interactions between the host and guest differ with each enantiomer of the guest. Consequently, host 3 can discriminate the chirality of the guest. The results of FABMS for $\operatorname{Trp}-\mathrm{O}_{-}{ }^{i} \mathrm{Pr}^{+}$having a large substituent group, such as an indole moiety, can be accounted for by this chiral recognition mechanism of host 3 .

When the open space is large around the ammonium ion of the chiral guest in the host-guest complex, the difference in the steric effects between the enantiomers of the chiral guest reduces (Schemes 2(e) and (f)). Because of the loose packing structure of the complex ion, host 4 possibly does not show enantioselectivity toward a given protonated amino acid ester guest.

\section{Conclusions}

By using the FABMS/EL guest method, it was clarified that one of the newly synthesized chiral hosts showed chiral discrimination toward several protonated amino acid ester guests. Another host showed no enantioselectivity toward the given guests, since the host made a host-guest complex with loose packing for the longer oxyethylene chain and the highly steric modified monosaccharide moieties. The steric effects are essential factors in large chiral recognition, but the degree must be controlled so as to prevent these effects from causing repulsion between the host and guest. In the case of acyclic chiral hosts, which consist of an oxyethylene chain moiety linked to modified saccharide moieties at both ends, the isopropylidene or methyl groups are typical suitable substituent groups for chiral recognition.

We hope that other useful chiral hosts will be discovered by the FABMS/EL guest method and applied to chiral stationary phases of chromatography, chiral selectors for capillary electrophoresis, chiral ligands for NMR shift reagents, and catalysts for asymmetric synthesis.

\section{Acknowledgments}

We are grateful to Dr. Masami Sawada (The Institute of Scientific and Industrial Research, Osaka University) for stimulation and encouragement.

\section{References}

1) X. X. Zhang, J. S. Bardshaw, and R. M. Izatt, Chem. Rev., 97, 3313 (1997).
2) E. L. Izake, J. Pharm. Sci., 96, 1659 (2007).

3) N. M. Maier, P. Franco, and W. Lindner, J. Chromatogr. A, 906, 3 (2001).

4) M. Sawada, Y. Takai, H. Yamada, T. Kaneda, K. Kamada, T. Mizooku, K. Hirose, Y. Tobe, and K. Naemura, J. Chem. Soc., Chem. Commun., 2497 (1994).

5) M. Sawada, et al., J. Am. Chem. Soc., 117, 7726 (1995).

6) M. Sawada, "The Encyclopedia of Mass Spectrometry"; Vol. 4, ed. by N. M. M. Nibbering, Elsevier, Amsterdam (2005), Part H06, p. 740.

7) M. Sawada, Y. Takai, H. Imamura, H. Yamada, S. Takahashi, H. Yamaoka, K. Hirose, Y. Tobe, and J. Tanaka, Eur. J. Mass Spectrom., 7, 447 (2001).

8) M. Shizuma, H. Adachi, Y. Takai, M. Hayashi, J. Tanaka, T. Takeda, and M. Sawada, Carbohydr. Res., 335, 275 (2001).

9) M. Shizuma, H. Adachi, D. Ono, H. Sato, and M. Nakamura, Chirality, 21, 324 (2009).

10) M. Shizuma, H. Adachi, M. Kawamura, Y. Takai, T. Takeda, and M. Sawada, J. Chem. Soc., Perkin Trans. 2, 592 (2001).

11) M. Shizuma, Y. Kadoya, Y. Takai, H. Imamura, H. Yamada, T. Takeda, R. Arakawa, S. Takahashi, and M. Sawada, J. Org. Chem., 67, 4795 (2002).

12) M. Shizuma, H. Imamura, Y. Takai, H. Yamada, T. Takeda, S. Takahashi, and M. Sawada, Chem. Lett., 29, 1292 (2000).

13) K. Hirose, A. Fujiwara, K. Matsunaga, N. Aoki, and Y. Tobe, Tetrahedron Lett., 43, 8539 (2002).

14) K. Hirose, A. Fujiwara, K. Matsunaga, N. Aoki, and Y. Tobe, Tetrahedron-Asymmetry, 14, 555 (2003).

15) K. Sada, Y. Tateishi, and S. Shinkai, Chem. Lett., 33, 582 (2004).

16) A. E. Lovely and T. J. Wenzel, Org. Lett., 8, 2823 (2006).

17) A. E. Lovely and T. J. Wenzel, Chirality, 20, 370 (2008).

18) E. P. Kyba, J. M. Timko, L. J. Kaplan, F. de Jong, G. W. Gokel, and D. J. Cram, J. Am. Chem. Soc., 100, 4555 (1978).

19) M. A. Coplan and R. M. Fouss, J. Phys. Chem., 68, 1177 (1964).

20) R. D. Guthrie and J. Honeyman, J. Chem. Soc., 1959, 853 (1959).

21) P. J. Garegg and T. Inversen, Carbohydr. Res., 70, C13 (1979).

22) C. P. J. Glaudemans, E. Zissis, and M. Jolley, Carbohydr. Res., 40, 129 (1974).

23) R. P. Bonar-Law and J. K. M. Sanders, J. Am. Chem. Soc., 117, 259 (1995).

24) K. Hirose, J. Incl. Phenom., 39, 193 (2001).

25) T. Tsukube and H. Sohmiya, J. Org. Chem., 56, 875 (1991).

26) M. Bourgoin, K. H. Wong, J. Y. Hui, and J. Smid, J. Am. Chem. Soc., 97, 3462 (1975).

27) T. Arimura, M. Kubota, T. Matsuda, O. Manabe, and S. Shinkai, Bull. Chem. Soc. Jpn., 62, 1674 (1989).

Keywords: Fast atom bombardment mass spectrometry, Chiral discrimination, Chiral host, Amino acid ester, Hostguest complexation 